\title{
Treating to target of minimal disease activity and normal function in polyarticular juvenile idiopathic arthritis with adalimumab: analysis from a phase 3 clinical trial
}

Nicola Ruperto ${ }^{1 *}$, Daniel Lovell ${ }^{2}$, Pierre Quartier ${ }^{3}$, Angelo Ravelli ${ }^{4}$, Mahinda Karunaratne ${ }^{5}$, Jasmina Kalabic ${ }^{6}$, Anabela Cardoso ${ }^{7}$, Alberto Martini ${ }^{1}$, Gerd Horneff ${ }^{8}$

From 21st European Pediatric Rheumatology (PReS) Congress

Belgrade, Serbia. 17-21 September 2014

\section{Introduction}

The Juvenile Arthritis Disease Activity Score (JADAS) [1] is becoming widely accepted in juvenile idiopathic arthritis (JIA) for defining a treat to target strategy.

\section{Objectives}

To evaluate patients (pts) treated with adalimumab (ADA) ( \pm methotrexate $[\mathrm{MTX}])$ that achieved minimal disease activity (MDA) and both MDA and normalization of function.

\section{Methods}

This post hoc analysis assessed pts aged 4-17 with polyarticular JIA enrolled in a phase 3 clinical trial (DE038)[2], which consisted of a 16 week (wk) open-label (OL) leadin with $\mathrm{ADA} \pm \mathrm{MTX}, 32 \mathrm{wk}$ double-blind (DB) phase with ADA or placebo $(\mathrm{PBO}) \pm \mathrm{MTX}$, and OL extension (OLE) with ADA \pm MTX up to 346wks. Outcomes were assessed by 27-joint JADAS (JADAS27), based on C-reactive protein, and Childhood Health Assessment Questionnaire Disability Index (CHAQ-DI). MDA was defined as JADAS27<3.8 and normal function as CHAQ-DI $<0.5$. Pts who entered the DB phase were included; data were stratified by MTX treatment (tx) at entry.

\section{Results}

At baseline, 75 pts on MTX had a mean JADAS27 of 21.2 and CHAQ-DI of 0.9 , and 58 pts who were MTX naïve or had withdrawn from MTX had a mean JADAS27 of

\section{${ }^{1}$ PRINTO-IRCCS, Genova, Italy

Full list of author information is available at the end of the article
23.8 and CHAQ-DI of 1.2. After 16wks of OL ADA, the mean JADAS27 was 6.1 and 6.7 and CHAQ-DI was 0.4 and 0.5 for ADA+MTX and ADA-MTX, respectively. Clinical improvements were seen at wk48 and wk88, and the mean JADAS27 at wk88 was 2.6, 3.0, 4.3, and 5.0 for ADA+MTX, ADA-MTX, PBO+MTX, and PBO-MTX, respectively. No pts had MDA or normal function at baseline; however, a good proportion achieved MDA and normal function during OL ADA. Fewer pts achieved MDA and normal function in the PBO tx compared with ADA continuation at both wk 48 and wk88. Table 1 .

P-value based on Cochran-Mantel-Haenszel statistics to test if there was a difference between ADA continuation vs. $\mathrm{PBO}$.

\section{Conclusion}

ADA \pm MTX resulted in a high percentage of pts achieving/ sustaining MDA and normal function. Some improvement

\section{Table 1}

\begin{tabular}{llllll}
\hline n (\%) & \multicolumn{5}{c}{ Minimal Disease Activity } \\
\cline { 2 - 6 } & \multicolumn{4}{c}{ ADA Continuation } & \multicolumn{3}{c}{ PBO } & P-value \\
\cline { 2 - 6 } & +MTX & -MTX & +MTX & -MTX \\
\hline Week 16 & $28(37.3)$ & $19(33.9)$ & NA & NA & NA \\
\hline Week 48 & $19(76.0)$ & $14(56.6)$ & $15(62.5)$ & $13(68.4)$ & 0.8919 \\
\hline Week 88 & $26(83.9)$ & $20(76.9)$ & $14(50.0)$ & $13(65.0)$ & 0.0075 \\
\hline \multicolumn{5}{c}{ Minimal Disease Activity with } & Normal Function \\
\hline Week 16 & $21(28.0)$ & $15(26.8)$ & NA & NA & NA \\
\hline Week 48 & $17(68.0)$ & $12(48.0)$ & $15(62.5)$ & $13(68.4)$ & 0.5155 \\
\hline Week 88 & $24(77.4)$ & $17(65.4)$ & $14(50.0)$ & $11(55.0)$ & 0.0362 \\
\hline
\end{tabular}


was seen with $\mathrm{PBO}$ during the $\mathrm{DB}$ period, but continued ADA tx shows better overall outcomes. A target of comprehensive disease control with MDA and normal function is achievable and aligned with current goals of JIA tx.

\section{Trial registration identifying number}

\section{NCT00048542}

\section{Disclosure of interest}

N. Ruperto Grant / Research Support from: AbbVie, AstraZeneca, BMS, Janssen Biologics BV, Eli Lilly \& Co, "Francesco Angelini", GlaxoSmithKline, Italfarmaco, Novartis, Pfizer, Roche, Sanofi Aventis, Schwarz Biosciences $\mathrm{GmbH}$, Xoma, Wyeth Pharmaceuticals, Employee of: GASLINI Hospital, Speaker Bureau of: Astellas, AstraZeneca, BMS, Italfarmaco, Janssen Biologics B.V., MedImmune, Roche, Wyeth/Pfizer, D. Lovell Consultant for: AbbVie, AstraZeneca, Centocor, BMS, Pfizer, Regeneron, Hoffman La-Roche, Novartis, UBC, Genentech, Xoma, Amgen, Forest Research, Speaker Bureau of: Wyeth Pharmaceuticals, P. Quartier Grant / Research Support from: AbbVie, Novartis, Pfizer, BMS, ChugaiRoche, Medimmune, Servier, Swedish Orphan Biovitrum, Consultant for: AbbVie, Novartis, Pfizer, BMS, ChugaiRoche, Medimmune, Servier, Swedish Orphan Biovitrum, A. Ravelli Grant / Research Support from: Pfizer, Consultant for: Hoffman La-Roche, Speaker Bureau of: Hoffman La-Roche, Centocore, BMS, Pfizer, Novartis, AbbVie, M. Karunaratne Shareholder of: AbbVie, Employee of: AbbVie, J. Kalabic Shareholder of: AbbVie, Employee of: AbbVie, A. Cardoso Shareholder of: AbbVie, Employee of: AbbVie, A. Martini Grant / Research Support from: AbbVie, AstraZeneca, BMS, Janssen Biologics BV, Eli Lilly \& Co, "Francesco Angelini", GlaxoSmithKline, Italfarmaco, Naovartis, Pfizer, Roche, Sanofi Aventis, Schwarz Biosciences GmbH, Xoma, Wyeth Pharmaceuticals, Employee of: GASLINI Hospital, Speaker Bureau of: Astellas, AstraZeneca, BMS, Italfarmaco, MedImmune, G. Horneff Grant / Research Support from: AbbVie, Pfizer, Roche, Speaker Bureau of: AbbVie, Novartis, Pfizer, Roche.

\section{Authors' details}

${ }^{1}$ PRINTO-IRCCS, Genova, Italy, ${ }^{2}$ PRCSG, Cincinnati Children's Hospital Medical Center, Cincinnati, USA. ${ }^{3}$ Hopital Necker-Enfants Malades, Paris, France. ${ }^{4}$ Istituto G. Gaslini and Università degli Studi di Genova, Genova, Italy.

${ }^{5}$ AbbVie Inc., North Chicago, USA. ${ }^{6}$ AbbVie Deutschland GmbH \& Co. KG, Ludwigshafen, Germany. ${ }^{7}$ AbbVie, Amadora, Portugal. ${ }^{8}$ Asklepios Klinik Sankt Augustin, Sankt Augustin, Germany.

\section{Published: 17 September 2014}

\section{References}

1. Consolaro A, et al: Arthritis Rheum 2012.

2. Lovell DJ, et al: NEJM 2008.
doi:10.1186/1546-0096-12-S1-P9

Cite this article as: Ruperto et al:: Treating to target of minimal disease activity and normal function in polyarticular juvenile idiopathic arthritis with adalimumab: analysis from a phase 3 clinical trial. Pediatric

Rheumatology 2014 12(Suppl 1):P9.
Submit your next manuscript to BioMed Central and take full advantage of:

- Convenient online submission

- Thorough peer review

- No space constraints or color figure charges

- Immediate publication on acceptance

- Inclusion in PubMed, CAS, Scopus and Google Scholar

- Research which is freely available for redistribution 